\title{
A Maturity Model for the Deployment of Systems Engineering Processes
}

\author{
Clémentine Cornu \\ Eurocopter - ETZR \\ Aéroport International Marseille Provence, \\ 13725 Marignane Cedex - France \\ Clementine.Cornu@eurocopter.com
}

\author{
Vincent Chapurlat \\ Ecole des Mines d'Alès - LGI2P \\ Site EERIE de l'EMA, Parc Scientifique George Besse \\ 30035 Nîmes cedex 1 - France \\ Vincent.Chapurlat@mines-ales.fr
}

\author{
Jean-Marc Quiot \\ Eurocopter - ETZR \\ Aéroport International Marseille Provence, \\ 13725 Marignane Cedex - France \\ Jean-Marc.Quiot@eurocopter.com \\ François Irigoin \\ Mines ParisTech - CRI \\ 35 rue Saint Honoré, \\ 77305 Fontainebleau Cedex - France \\ Francois.Irigoin@mines-paristech.fr
}

\begin{abstract}
Nowadays, increasing competition on markets forces companies to improve constantly their competitiveness. For this, they have to control not only the design cycles of their products thanks to an efficient and responsive organization, but also interactions between people, processes and technologies involved in design. However, it is problematic considering the increasing complexity of products. A solution is to apply the principles of Systems Engineering (SE), a proven interdisciplinary approach that defines an effective organization in the form of processes. However it raises a set of questions such as: how to define SE compliant processes including business specificities and how to know if the company has the required organization and skills to deploy them successfully? This article aims to answer this last question for large companies designing complex products under the assumption that interoperability, i.e. the ability to work efficiently together, is a deployment key factor. On the basis of a survey of existing contributions applicable to the deployment, we introduce an innovative maturity model to be used before any deployment action. This paper explains the design approach used to elaborate and validate it, presents its content and shows how to use it.
\end{abstract}

Keywords - Systems Engineering processes deployment; Maturity model; Enterprise Systems Engineering; Interoperability; Enterprise Modelling

\section{INTRODUCTION}

The Systems Engineering (SE) approach is a tried and tested approach that promotes and coordinates all appropriate processes to design, develop and test a system. Therefore many companies aim to introduce this method and the appropriate corresponding organization in their design offices. But to deploy SE principles and processes in a company remains a non trivial activity that requires a deployment method and unfortunately very few methods detailing how to deploy SE in companies are published [1-3] and existing ones are hardly applicable in industry considering their textual nature and highlevel of abstraction.
To clear this hurdle a detailed model-based method has been developed $[4,5]$. The latter particularly emphasizes the need to prepare the company and its entities for the deployment in order to anticipate future difficulties inherent to it. Thus, an appraisal tool is needed to assess their readiness for the changes induced by the deployment before any deployment action. This tool has to meet many requirements. For instance, for pragmatic industrial reasons, it must be directly and easily applicable by the company, promote re-use, be pedagogical, and be open-ended for possible future modifications. By the way, this tool should also consider interoperability i.e. the "ability of enterprises and entities within those enterprises to communicate and interact effectively" [6]. Indeed, SE is an interdisciplinary approach that implies a huge number of interactions between people, technologies and processes [7]. So, we assume that interoperability of all resources involved or that could be involved in the future processes to deploy is a key factor in the deployment of SE processes that must be considered and appraised [8] during the preparation of the deployment.

Unfortunately, as far as we know, no existing appraisal mean meets all these requirements. We have thus developed a solution that is presented in this article structured as follows. Section II introduces the approach we used to design a solution and its underlying scientific basis. Then Section III provides its details and finally, before concluding, Section IV illustrates how to use it pragmatically.

\section{TOWARDS A SOLUTION}

This Section aims to argue the decision consisting in developing a maturity model and then the approach used to design a solution from the needs previously identified. Scientific contributions used are also identified. 


\section{A. Towards a maturity model}

From a pragmatic point of view, in addition to the requirements previously identified, the solution should be mainly used by managers. Indeed, they need a tool to: 1) have an overview of the readiness of organisational units under their responsibilities to face a deployment of Systems Engineering (SE) processes and 2) identify in a synthetic way what and where the weaknesses of their organizations endangering the future deployment are. To that end, a maturity model (MM) can be used. Classically it is represented as a matrix with one dimension describing the assessment criteria, and the other the maturity levels. It enables detecting on which criteria improvements must be done to move from a given level to a better one. In a deployment context, MMs appear relevant since they are easy to use, open-ended and enable making an initial assessment to track progress achieved while making managers \& design stakeholders become aware of their organisation's maturity. Moreover, they provide help in the selection of priority improvement topics and support gradual improvement. Finally, they support the selection of the best deployments scenarios according to the resulting maturity. Thus, taking into consideration industrial pragmatic expectations, a maturity model appears to be a good solution. It is a simple tool enabling having synthetic results for topmanagers and detailed results for improvement teams. However, one may think that it is redundant considering CMMI ${ }^{\circledR}[9]$, but it is not: they do not have the same purpose. CMMI ${ }^{\circledR}$ aims to help companies to assess the current performances of their processes and to provide guidelines to improve them, whereas our maturity model aims to assess the readiness of companies and entities within companies to deploy SE. They are thus complementary.

\section{B. Design approach and scientific foundations}

To design our maturity model, we studied literature about maturity models design such as [10] and examples of existing maturity model like [9, 11-13]. Then we analysed existing contributions applicable for the deployment. Firstly, we looked at work done about SE to know what should be deployed [1416], what skills are required [17-19], and what the existing published deployment methods are [1-3]. We also examined publications about the new tendency of SE, model-based SE [20], to include them in our work. Secondly, we analysed contributions in Enterprise SE [21, 7], architecture [22-24] and modelling [25], to collect methods and tools relevant to assess and improve companies' performances. Thirdly, we surveyed works about change management [26] to better lead enterprise transformations and facilitate the deployment considering human factors. Finally, we analysed contributions about interoperability $[27,6,13]$ to know the associated problems and existing means to evaluate interoperability of companies' resources. On the basis of this survey and industrial feedbacks, we designed first the structure of our maturity model (presented in the next Section) and then its content (see Appendix). The resulting maturity model has been submitted to a group of design office experts of a helicopter manufacturer for validation and has been applied on a real organisation to check and improve its content and ease of use within real organisations.

\section{STRUCTURE OF THE PROPOSED MATURITY MODEL}

This section details the structure of the proposed maturity model, i.e. its levels and factors. For the sake of readability of readability, the full maturity model is not provided in this section but in Appendix. In this maturity model, the word "entity" is used to refer to the assessment target. The latter can be a company, or one of its organisational units such as a design office, or a specific department or team.

Table 1 provides the five maturity levels we propose along with a catchphrase illustrating typical mindset of people in the organisation assessed at a specific level. This table includes also a reference to $\mathrm{CMMI}{ }^{\circledR}$ levels. The purpose of this last column (requested by some managers during its design) is to provide an idea of the maximum $C M M I \circledR ~ l e v e l$ that can be reached if we would assess the organisation considered. This information is interesting if the company is involved or intents to be involved in a CMMI ${ }^{\circledR}$ deployment approach.

TABLE I. MATURITY LEVELS

\begin{tabular}{|c|c|c|}
\hline Maturity Level & Catch phrase & \begin{tabular}{|c} 
Max CMMI® \\
level
\end{tabular} \\
\hline 1 INITIAL & "SE!? What is it?!?" & \multirow[b]{2}{*}{1} \\
\hline LOW & $\begin{array}{l}\text { "SE? No use to deploy it, we have } \\
\text { always applied its principles" }\end{array}$ & \\
\hline NEUTRAL & $\begin{array}{l}\text { "SE is great but we are not ready for it } \\
\text { in our company" }\end{array}$ & \multirow{2}{*}{2} \\
\hline GOOD & "SE: Why not?" & \\
\hline 5 EXCELLENT & "Let's fully apply SE principles!" & 3 \\
\hline
\end{tabular}

Table 2 provides assessments criteria ("factors") constituting the second dimension of the maturity model. We have organized them according to three dimensions: "Processes", "People" and "Methods and Tools". The latter have been proposed in the NASA Systems Engineering framework [28] though some minor wording changes have been made to better fit to the vocabulary used within the company in which the maturity model has been developed. In order to consider the interoperability, as we have assumed that it is a key factor in the deployment, Table 2 also indicates for each assessment criterion the interoperability barrier(s) it aims to overcome. An interoperability barrier can be defined as a classification of interoperability problems. For the purpose of this research, we have retained the problems characterization of the INTEROP-NOE project [27] that proposes three "interoperability barriers":

- Technological barrier: problems relating to the "lack of a set of compatible technologies which prevent collaboration between two or more systems",

- Conceptual barrier: problems relating to "the syntactic and semantic differences of information to be exchanged as well as the expressivity of the information" with expressivity defined as "ability to represent and communicate knowledge in a pragmatic and easy to understand way", 
- Organizational barrier: problems relating to "the definition of responsibility and authority so that interoperability can take place under good conditions".

TABLE II. ASSESSMENT CRITERIA AND INTEROPERABILITY BARRIERS

\begin{tabular}{|c|c|c|c|c|c|}
\hline & & & Conc & Org & Tech \\
\hline & & ENGINEERING PROCESSES & & & \\
\hline & 至 & $\begin{array}{l}\text { Consistency \& standardisation of engineering } \\
\text { activities }\end{array}$ & $\mathrm{X}$ & $\mathrm{X}$ & $\mathrm{X}$ \\
\hline & 跑 & Type of design & & $\mathrm{X}$ & \\
\hline & 峁 & TECHNICAL MANAGEMENT PROCESSES & & & \\
\hline $\begin{array}{l}\bar{n} \\
\hat{x} \\
0\end{array}$ & 岕 & $\begin{array}{l}\text { Consistency \& standardisation of technical } \\
\text { management activities }\end{array}$ & $\mathrm{X}$ & $\mathrm{X}$ & $\mathrm{X}$ \\
\hline 芫 & i & $\begin{array}{l}\text { Definition of interfaces, R\&R, constraints of } \\
\text { stakeholders all along design technical \& } \\
\text { management activities }\end{array}$ & $\mathrm{X}$ & $\mathrm{X}$ & \\
\hline & 柔 & $\begin{array}{l}\text { Existence of a team responsible for the design office } \\
\text { practices standardization \& overall improvement }\end{array}$ & & X & \\
\hline & $\frac{1}{2}$ & Design processes modelling & $\mathrm{X}$ & $\mathrm{X}$ & \\
\hline & & REQUIRED SKILLS & & & \\
\hline & & Engineering & $\mathrm{X}$ & & \\
\hline & & Project management & $\mathrm{X}$ & & \\
\hline & $\tilde{3}$ & Systems Engineering & $\mathrm{X}$ & & \\
\hline & $\overrightarrow{\bar{n}}$ & Modelling & $\mathrm{X}$ & & \\
\hline 되 & & $\begin{array}{l}\text { MANAGEMENT AND DEVELOPMENT OF } \\
\text { SKILLS }\end{array}$ & & & \\
\hline $\overrightarrow{0}$ & & Training & $\mathrm{X}$ & $\mathrm{X}$ & \\
\hline 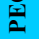 & & Validation of skills & $\mathrm{X}$ & $\mathrm{X}$ & \\
\hline & & Establishment of a "sense of urgency" & & $\mathrm{X}$ & \\
\hline & 5 & Establishment of a "powerful guiding coalition" & & $\mathrm{X}$ & \\
\hline & $\tilde{\hat{\eta}}$ & Visions of top management & $\mathrm{X}$ & $\mathrm{X}$ & \\
\hline & $\sum_{\substack{11 \\
\omega}}^{E}$ & $\begin{array}{l}\text { Arbitration between project short-term vision and SE } \\
\text { deployment long term vision }\end{array}$ & & $\mathrm{X}$ & \\
\hline & & $\begin{array}{l}\text { Involvement of managers in the SE deployment } \\
\text { project }\end{array}$ & & $\mathrm{X}$ & \\
\hline$\infty$ & 岁 & $\begin{array}{l}\text { Capacity to exchange \& share information within the } \\
\text { entity }\end{array}$ & $\mathrm{X}$ & $\mathrm{X}$ & $\mathrm{X}$ \\
\hline 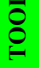 & 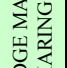 & $\begin{array}{l}\text { Capitalization, formalization and sharing of } \\
\text { knowledge about design engineering activities }\end{array}$ & $\mathrm{X}$ & $\mathrm{X}$ & \\
\hline 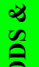 & 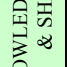 & $\begin{array}{l}\text { Capitalization, formalization and sharing of } \\
\text { knowledge about design technical management }\end{array}$ & $\mathrm{X}$ & $\mathrm{X}$ & \\
\hline$\underline{\underline{E}}$ & $\underline{z}$ & Sharing of artefacts templates & $\mathrm{X}$ & $\mathrm{X}$ & \\
\hline$\sum$ & ${ }_{\substack{n \\
0}}^{n}$ & Design tools standardization & & & $X$ \\
\hline
\end{tabular}

Thus, this section detailed the structure of the maturity model and the Appendix provided its details. Nevertheless, to explicit its use, Section IV explains how to apply it.

\section{APPLICATION OF THE MATURITY MODEL}

To use our maturity model is quite simple. For each assessment criterion (i.e. for each row) of the maturity model provided in Appendix, the assessor looks at all descriptions provided and picks the one that best describes the situation in the entity he is currently assessing. For instance, for the first row ("Consistency \& standardisation of engineering activities"), if the description of level 4 "Some initiatives to standardize design practices between some projects" is the best description of the entity assessed, then this row get a score of "4". This work is performed for each row. Then the means of all scores by dimension and globally are computed. To facilitate the use of the maturity model, we have designed a computer application to automate this calculus and generate graphical synthesis (see Figures 1 and 2).

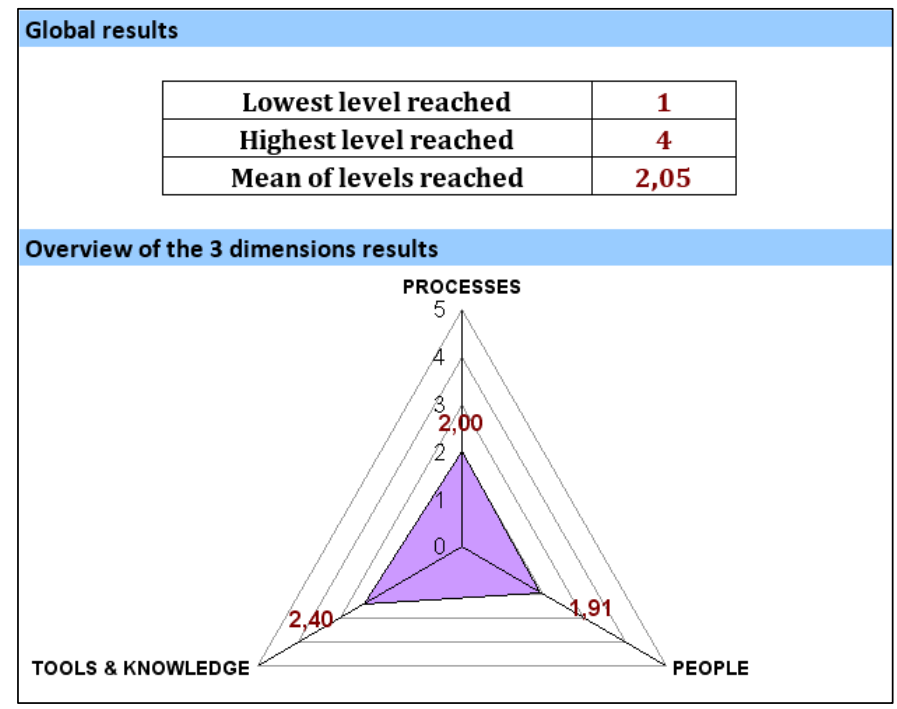

Figure 1. Example of global assessment synthesis

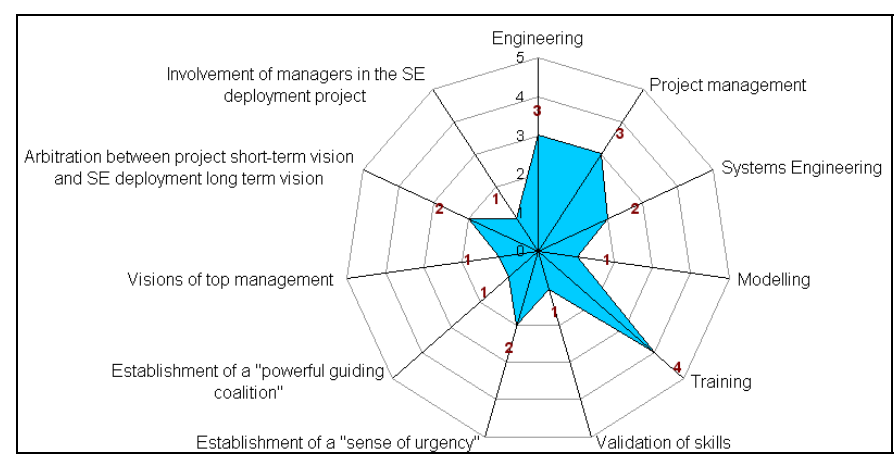

Figure 2. Example of detailed assessment (People dimension)

If the global score (labelled "means of levels reached" on Figure 1) is less than 4, we encourage the company to improve the entity assessed before deploying new SE processes. To this end, two strategies can be selected. Either the company picks one dimension and improves its factors until reaching a level of 4; or it improves the abilities of the entity assessed starting with the factor with the lowest score using synthesis such as the one illustrated in Figure 2.

\section{CONCLUSION AND OUTLOOK}

This article presents an innovative easy to use maturity model to assess the readiness of a company and its components to face a deployment of Systems Engineering (SE) processes before any deployment action. This maturity model has been designed by and for industrials with the goal to be an openended pragmatic solution to the needs of managers having to introduce SE in their design offices. Its originality is to 
consider the interoperability of resources constituting the entity assessed in order to maximize the probability of success of the inevitable company's transformation required by $\mathrm{SE}$ application. By the way, it can also be used to have a first idea of the maximal CMMI ${ }^{\circledR}$ level that the entity could reach. Thus, the contribution introduced in this paper, tested and improved within a helicopter manufacturer, aims to support the promotion and application of SE within large companies while considering interoperability and respecting Enterprise SE principles.

\section{REFERENCES}

[1] A. Sienou, "Proposition d'un cadre métholodogique pour le management intégré des risques et des processus d'entreprise," Ph.D. dissertation, Institut National Polytechnique de Toulouse, 2009, last access: 28.10.11. [in French]. [Online]. Available: http://ethesis.inp-toulouse.fr/archive/00000878/

[2] S. Rochet, "Formalisation des processus de l'ingénierie système : Proposition d'une méthode d'adaptation des processus génériques à différents contextes d'application," Ph.D. dissertation, Université de Toulouse, 2007, last access: 28.10.11. [in French]. [Online]. Available: http://eprint.insa-toulouse.fr/archive/00000162/01/Rochet.pdf

[3] AFIS, “Ingénierie système - Pourquoi ? Comment ?" Association Française d'Ingénierie Système, Tech. Rep., 2005, [in French]. [Online]. Available: http://www.afis.fr/default.aspx

[4] C. Cornu, V. Chapurlat, B. Chiavassa, and F. Irigoin, "Mixing Systems Engineering and Enterprise Modelling principles to formalize a se processes deployment approach in industry," in Complex Systems Design \& Management (CSD\&M), Paris, France, 7-9 December 2011, 2011.

[5] C. Cornu, V. Chapurlat, J.-M. Quiot, and F. Irigoin, "Application of an Enterprise Modelling approach to deploy Systems Engineering processes in large organizations," 2012, SoSyM, unpublished.

[6] ISO, "ISO/DIS 11354-1 - Advanced automation technologies and their applications - Part 1: Framework for enterprise interoperability," ISO, Tech. Rep., 2010. [Online]. Available: http://www.iso.org/iso/catalogue_detail.htm?csnumber $=50417$

[7] R. S. Swarz and J. K. DeRosa, "A framework for enterprise systems engineering processes," in ICSSEA 2006 Swarz \& Derosa, 2006.

[8] C. Cornu, V. Chapurlat, J.-M. Quiot, and F. Irigoin, "Interoperability Assessment in the Deployment of Technical Processes in Industry," 2012, INCOM 2012, in press.

[9] SEI, “CMMI for development, version 1.3," SEI, Tech. Rep., 2010.

[10] ISO, “ISO/IEC 15504:2004 - Information technology - Process assessment," International Organization for Standardization, Tech. Rep., 2004.

[11] W. Guédria, D. Chen, and Y. Naudet, "A maturity model for enterprise interoperability," in R. Meersman, P. Herrero, and T. Dillon (Eds.): OTM 2009 Workshops, 2009, pp. 216-225. [Online]. Available: http://www.springerlink.com/content/p0w116875089307h/

[12] SEI, "People CMM," 2010. [Online]. Available: http://www.sei.cmu.edu/cmmi/tools/peoplecmm/

[13] C4ISR, "Levels of information systems interoperability (LISI)," C4ISR, Tech. Rep., 1998, last access: 28.10.11. [Online]. Available: http://www.eng.auburn.edu/ hamilton/security/DODAF/LISI.pdf
[14] ISO/IEC, “ISO/IEC 15288:2008 - systems engineering - system life cycle processes," International Organization for Standardization, Tech. Rep., 2008. [Online]. Available: http://www.iso.org/iso/catalogue_detail?csnumber $=43564$

[15] INCOSE, "Systems Engineering Handbook - A guide for system life cycle processes and activities - v3.2," INCOSE, Tech. Rep., January 2010. [Online]. Available: http://www.incose.org/ProductsPubs/products/sehandbook.aspx

[16] R. Shishko and R. Chamberlain, "NASA Systems Engineering Handbook," National Aeronautics and Space Administration, Tech. Rep., December 2007, last access: 28.10.11. [Online]. Available: http://education.ksc.nasa.gov/esmdspacegrant/Documents/NASA\%20SP2007-6105\%20Rev\%201\%20Final\%2031Dec2007.pdf

[17] P. Jansma and M. Derro, "If you want good systems engineers, sometimes you have to grow your own!" in Aerospace Conference, 2007 IEEE, 2007. [Online]. Available: http://ieeexplore.ieee.org/xpl/freeabs_all.jsp?tp $=\&$ arnumber $=4161711$ \&isnumber $=4144550$

[18] M. E. Derro and C. R. Williams, "Behavioral competencies of highly regarded systems engineers at NASA," in 2009 IEEE Aerospace conference. Ieee, 2009, pp. 1-17. [Online]. Available: http://ieeexplore.ieee.org/lpdocs/epic03/wrapper.htm?arnumber $=4839712$

[19] S. Arnold, "Transforming systems engineering principles into integrated project team practice," Ph.D. dissertation, Cranfield university, 2008, last access: 28.10.11. [Online]. Available: https://dspace.lib.cranfield.ac.uk/handle/1826/3033

[20] J. A. Estefan, "Survey of model-based systems engineering (MBSE) methodologies," INCOSE, Tech. Rep., June 2008.

[21] B. E. White, "INCOSE Symposium, 20-23 june 2011, Denver, CO ," 2011.

[22] J. Zachman, "A framework for information systems architecture reprint," IBM systems journal, vol. 38, no. 2/3, pp. 454-470, 1999.

[23] TOGAF, “TOGAF version 9," The Open Group, Tech. Rep., 2009.

[24] DoD, "DoD architecture framework - version 1.5," DoD, Tech. Rep., 2007.

[25] M. Petit and G. Doumeingts, "Deliverable D1.1 - Report on the state of the art in enterprise modelling," Project UEML : Unified Enterprise Modelling Language, Tech. Rep., 2002.

[26] J. P. Kotter, "Leading change why transformation efforts fail," Harvard Business Review, 2006.

[27] INTEROP-NoE, "Deliverable DI.2 - Enterprise interoperabilityFramework and knowledge corpus-Advanced report," Interoperability Research for Networked Enterprises Applications and Software, Tech. Rep., 2006, last access: 28.10.11. [Online]. Available: http://interopvlab.eu/ei_public_deliverables/interop-noe-deliverables/di-domaininteroperability/di-2-enterprise-interoperability-framework-andknowledge-corpus/attachment_download/file

[28] P. A. Jansma, "Let's roll! Rolling out the nasa systems engineering framework," in Aerospace conference 2009 IEEE, 2009, pp. 1-18. 
APPENDIX: The Proposed MATURITY MODEL

\begin{tabular}{|c|c|c|c|c|c|}
\hline Maturity Level & 1 - INITIAL & 2 - LOW & 3 - NEUTRAL & 4 - GOOD & 5 - EXCELLENT \\
\hline \multicolumn{6}{|c|}{ PROCESSES } \\
\hline \multicolumn{6}{|c|}{ TECHNICAL PROCESSES } \\
\hline \multicolumn{6}{|c|}{ ENGINEERING PROCESSES } \\
\hline $\begin{array}{l}\text { Consistency \& } \\
\text { standardisation of } \\
\text { engineering activities }\end{array}$ & $\begin{array}{l}\text { Projects specific } \\
\text { heterogeneous design } \\
\text { activities. No consistency } \\
\text { or standardization within } \\
\text { the project. }\end{array}$ & $\begin{array}{l}\text { Projects specific } \\
\text { heterogeneous design } \\
\text { practices. Every project has } \\
\text { its own practices } \\
\text { independently from the } \\
\text { others but within a project } \\
\text { activities are standardized } \\
\text { but not formalised. }\end{array}$ & $\begin{array}{l}\text { Projects specific } \\
\text { heterogeneous design } \\
\text { practices. Every project has } \\
\text { its own practices } \\
\text { independently from the others } \\
\text { but within a project activities } \\
\text { are standardized and } \\
\text { formalised. }\end{array}$ & $\begin{array}{l}\text { Some initiatives to standardize } \\
\text { design practices between some } \\
\text { projects. }\end{array}$ & $\begin{array}{l}\text { Standard design practices } \\
\text { common to all projects. }\end{array}$ \\
\hline Type of design & $\begin{array}{l}\text { Document-based design } \\
\text { managed with difficulties - } \\
\text { The entity is not mature } \\
\text { enough to apply the } \\
\text { principles of MBSE and } \\
\text { should focus on SE good } \\
\text { practices. }\end{array}$ & $\begin{array}{l}\text { Document-based design } \\
\text { globally managed within } \\
\text { the entity. }\end{array}$ & $\begin{array}{l}\text { Document-based design } \\
\text { managed. Initiatives to test } \\
\text { the use of models on projects } \\
\text { parts. }\end{array}$ & $\begin{array}{l}\text { Mainly document-based design } \\
\text { but some projects have adopted } \\
\text { model-based design. }\end{array}$ & $\begin{array}{l}\text { New projects are full model- } \\
\text { based design. }\end{array}$ \\
\hline \multicolumn{6}{|c|}{ TECHNICAL MANAGEMENT PROCESSES } \\
\hline $\begin{array}{l}\text { Consistency \& } \\
\text { standardisation of } \\
\text { technical management } \\
\text { activities }\end{array}$ & $\begin{array}{l}\text { Projects specific } \\
\text { heterogeneous design } \\
\text { practices. Every project } \\
\text { has its own practices } \\
\text { independently from the } \\
\text { others. }\end{array}$ & $\begin{array}{l}\text { Heterogeneous - Project } \\
\text { specific - A referential is } \\
\text { chosen in order to start to } \\
\text { standardise PM practices } \\
\text { but is not fully respected. }\end{array}$ & $\begin{array}{l}\text { Heterogeneous - Project } \\
\text { specific } \\
\text { A referential is chosen in } \\
\text { order to start to standardise } \\
\text { PM practices and is respected } \\
\text { within projects. }\end{array}$ & $\begin{array}{l}\text { Standard - Common basis for } \\
\text { all projects } \\
\text { A referential is chosen in order } \\
\text { to start to standardise PM } \\
\text { practices but is not fully } \\
\text { respected by all projects. }\end{array}$ & $\begin{array}{l}\text { Standard - Common basis for } \\
\text { all projects } \\
\text { A referential is chosen in } \\
\text { order to standardise PM } \\
\text { practices and is respected by } \\
\text { all projects. }\end{array}$ \\
\hline $\begin{array}{l}\text { Definition of interfaces, } \\
\text { R\&R, \& constraints of } \\
\text { stakeholders all along } \\
\text { design technical \& } \\
\text { management activities }\end{array}$ & $\begin{array}{l}\text { Implicit or not shared } \\
\text { definition of } \\
\mathrm{R} \& \mathrm{R} / \text { interfaces within } \\
\text { organisational units } \\
\text { constituting the entity. }\end{array}$ & $\begin{array}{l}\text { Formal, shared and applied } \\
\text { definition of } \\
\text { R\&R/interfaces within } \\
\text { organisational units } \\
\text { constituting the entity. }\end{array}$ & $\begin{array}{l}\text { Implicit or not shared } \\
\text { definition of R\&R/interfaces } \\
\text { between organisational units } \\
\text { constituting the entity and } \\
\text { involved in design activities. }\end{array}$ & $\begin{array}{l}\text { Formal, shared and applied } \\
\text { definition of R\&R/interfaces } \\
\text { between organisational units } \\
\text { constituting the entity. }\end{array}$ & $\begin{array}{l}\text { Standard definition of the } \\
\text { known mandatory constraints } \\
\text { affecting each organisational } \\
\text { unit involved in the design so } \\
\text { that all are aware and can deal } \\
\text { with them. }\end{array}$ \\
\hline \multicolumn{6}{|c|}{ PROCESSES MANAGEMENT } \\
\hline $\begin{array}{l}\text { Existence of a team } \\
\text { responsible for the } \\
\text { design office practices } \\
\text { standardization \& } \\
\text { overall improvement }\end{array}$ & $\begin{array}{l}\text { Missing - No team is } \\
\text { responsible for } \\
\text { standardizing the practices } \\
\text { of the various projects } \\
\text { within the entity. }\end{array}$ & $\begin{array}{l}\text { Existing but undersized. } \\
\text { Improvement solutions } \\
\text { delivered but without } \\
\text { providing their enablers, so } \\
\text { they are not really used. }\end{array}$ & $\begin{array}{l}\text { Existing but lacking the } \\
\text { necessary skills. } \\
\text { Improvement solutions } \\
\text { delivered but without } \\
\text { providing their enablers, so } \\
\text { they are not really used. }\end{array}$ & $\begin{array}{l}\text { Existing, properly sized and } \\
\text { maintained during } \\
\text { reorganizations. } \\
\text { Improvement solutions } \\
\text { delivered but without providing } \\
\text { their enablers, so they are not } \\
\text { really used. }\end{array}$ & $\begin{array}{l}\text { Existing, fairly sized and } \\
\text { maintained during } \\
\text { reorganizations. } \\
\text { Improvement complete } \\
\text { solutions delivered. }\end{array}$ \\
\hline $\begin{array}{l}\text { Design processes } \\
\text { modelling }\end{array}$ & $\begin{array}{l}\text { No formal process. } \\
\text { Modelling unused. }\end{array}$ & $\begin{array}{l}\text { Defined processes but with } \\
\text { a too high level of } \\
\text { abstraction to be usable } \\
\text { (Design office level). } \\
\text { No standard formalism / } \\
\text { semantics. }\end{array}$ & $\begin{array}{l}\text { Processes and activities } \\
\text { detailed and highly impacted } \\
\text { by a change of organization. } \\
\text { No standard formalism / } \\
\text { semantics. }\end{array}$ & $\begin{array}{l}\text { Processes and activities } \\
\text { detailed and highly impacted } \\
\text { by a change of organization. } \\
\text { Shared formalism (prefer } \\
\text { standard one) and semantics. }\end{array}$ & $\begin{array}{l}\text { Detailed processes and } \\
\text { activities designed to be } \\
\text { easily adapted according to } \\
\text { organisational changes. }\end{array}$ \\
\hline \multicolumn{6}{|c|}{ PEOPLE } \\
\hline \multicolumn{6}{|l|}{ SKILLS } \\
\hline \multicolumn{6}{|l|}{ REQUIRED SKILLS } \\
\hline Engineering & $\begin{array}{l}\text { Engineering is done in an } \\
\text { unorganized and } \\
\text { spontaneous way. }\end{array}$ & $\begin{array}{l}\text { Engineering is done in an } \\
\text { organized way but only } \\
\text { with the methods and tools } \\
\text { developed within the entity } \\
\text { over the years. }\end{array}$ & $\begin{array}{l}\text { Engineering is done in an } \\
\text { organized way but latest } \\
\text { methods and tools for } \\
\text { engineering are not monitored } \\
\text { or applied in a global way in } \\
\text { the entity. }\end{array}$ & $\begin{array}{l}\text { The entity knows the latest } \\
\text { methods and tools for } \\
\text { engineering but is not able to } \\
\text { apply/use them. }\end{array}$ & $\begin{array}{l}\text { The entity knows the latest } \\
\text { methods and tools for } \\
\text { engineering and is able to } \\
\text { apply/use them. }\end{array}$ \\
\hline Project management & Not known. & $\begin{array}{l}\text { Generally unknown or } \\
\text { misunderstood (and } \\
\text { misapplied). }\end{array}$ & $\begin{array}{l}\text { Generally known, but its full } \\
\text { application could not be } \\
\text { considered in the entity (lack } \\
\text { of skills). }\end{array}$ & $\begin{array}{l}\text { Its relevance is accepted and } \\
\text { understood locally. It could be } \\
\text { applied in a restricted } \\
\text { perimeter. }\end{array}$ & $\begin{array}{l}\text { Its relevance is accepted and } \\
\text { understood in the whole } \\
\text { entity. It could be fully } \\
\text { applied in any part of the } \\
\text { entity. }\end{array}$ \\
\hline Systems Engineering & Not known. & $\begin{array}{l}\text { Generally unknown or } \\
\text { misunderstood (and } \\
\text { misapplied). }\end{array}$ & $\begin{array}{l}\text { Generally known, but its full } \\
\text { application could not be } \\
\text { considered in the entity (lack } \\
\text { of skills). }\end{array}$ & $\begin{array}{l}\text { Its relevance is accepted and } \\
\text { understood locally. It could be } \\
\text { applied in a restricted } \\
\text { perimeter. }\end{array}$ & $\begin{array}{l}\text { Its relevance is accepted and } \\
\text { understood in the whole } \\
\text { entity. It could be fully } \\
\text { applied in any part of the } \\
\text { entity. }\end{array}$ \\
\hline Modelling & $\begin{array}{l}\text { Modelling practices and } \\
\text { benefits are not known. }\end{array}$ & $\begin{array}{l}\text { Modelling principles } \\
\text { generally unknown or } \\
\text { misunderstood (and } \\
\text { misapplied). }\end{array}$ & $\begin{array}{l}\text { Modelling is generally } \\
\text { known, but its application is } \\
\text { not considered in the entity } \\
\text { (lack of skills). }\end{array}$ & $\begin{array}{l}\text { Its relevance is accepted and } \\
\text { understood locally. It could be } \\
\text { applied in a restricted } \\
\text { perimeter. }\end{array}$ & $\begin{array}{l}\text { Its relevance is accepted and } \\
\text { understood in the whole } \\
\text { entity. It could be fully } \\
\text { applied in any part of the } \\
\text { entity. }\end{array}$ \\
\hline
\end{tabular}




\begin{tabular}{|c|c|c|c|c|c|}
\hline Maturity Level & 1 - INITIAL & 2 - LOW & 3 - NEUTRAL & 4 - GOOD & 5 - EXCELLENT \\
\hline Training & No internal training. & $\begin{array}{l}\text { Internal training available at } \\
\text { team level but impacted } \\
\text { people are not } \\
\text { systematically trained. }\end{array}$ & $\begin{array}{l}\text { Internal training available at } \\
\text { department level but } \\
\text { impacted people are not } \\
\text { systematically trained. }\end{array}$ & $\begin{array}{l}\text { Internal training available for } \\
\text { the whole entity but concerned } \\
\text { impacted are not systematically } \\
\text { trained. }\end{array}$ & $\begin{array}{l}\text { Internal training available for } \\
\text { the whole entity and all } \\
\text { impacted people are trained. }\end{array}$ \\
\hline Validation of skills & $\begin{array}{l}\text { Roles needed during the } \\
\text { deployment and the } \\
\text { execution of processes to } \\
\text { deploy are not known. }\end{array}$ & $\begin{array}{l}\text { Roles are identified and } \\
\text { formalized; but required } \\
\text { skills are not identified or } \\
\text { formalised. }\end{array}$ & $\begin{array}{l}\text { Roles required for SE } \\
\text { application are defined, } \\
\text { accepted and shared within } \\
\text { the entity. The required skills } \\
\text { are clearly identified. }\end{array}$ & $\begin{array}{l}\text { Means for the validations of } \\
\text { skills are defined and } \\
\text { developed (if necessary). }\end{array}$ & $\begin{array}{l}\text { The skills required for the } \\
\text { application of the SE claimed } \\
\text { by members of the entity (old } \\
\text { or new hires) are evaluated. }\end{array}$ \\
\hline \multicolumn{6}{|l|}{ SE MINDSET } \\
\hline $\begin{array}{l}\text { Establishment of a } \\
\text { "sense of urgency" } \\
\text { (see [26]) }\end{array}$ & Not established. & $\begin{array}{l}\text { Some warnings are raised } \\
\text { about difficulty in design. }\end{array}$ & $\begin{array}{l}\text { Evaluation of status of design } \\
\text { activities is done. }\end{array}$ & $\begin{array}{l}\text { Communication about the } \\
\text { necessity to deploy SE. }\end{array}$ & $\begin{array}{l}\text { "Sense of urgency" } \\
\text { established and shared by all. }\end{array}$ \\
\hline $\begin{array}{l}\text { Establishment of a } \\
\text { "powerful guiding } \\
\text { coalition" }\end{array}$ & Not established. & $\begin{array}{l}\text { Local team established but } \\
\text { with not enough power to } \\
\text { have impact. }\end{array}$ & $\begin{array}{l}\text { Team established with middle } \\
\text { managers. The team is more } \\
\text { focused on reflexion than real } \\
\text { action. }\end{array}$ & $\begin{array}{l}\text { "Powerful guiding coalition" } \\
\text { established. The team has } \\
\text { enough power to be focused on } \\
\text { action. }\end{array}$ & $\begin{array}{l}\text { "Powerful guiding coalition" } \\
\text { established and works as a } \\
\text { team outside the normal } \\
\text { hierarchy. }\end{array}$ \\
\hline $\begin{array}{l}\text { Visions of top } \\
\text { management }\end{array}$ & Missing or inaccessible. & $\begin{array}{l}\text { Clearly defined for product } \\
\text { and partnership policies but } \\
\text { not shared. }\end{array}$ & $\begin{array}{l}\text { Clearly defined for product } \\
\text { and partnership policies and } \\
\text { shared. }\end{array}$ & $\begin{array}{l}\text { Clearly defined for design } \\
\text { strategy and SE, but not shared. }\end{array}$ & $\begin{array}{l}\text { Clearly defined for design } \\
\text { strategy and SE, and shared. }\end{array}$ \\
\hline $\begin{array}{l}\text { Arbitration between } \\
\text { project short-term } \\
\text { vision and SE } \\
\text { deployment long term } \\
\text { vision }\end{array}$ & $\begin{array}{l}\text { No will to even consider } \\
\text { to change project practices } \\
\text { to introduce SE. }\end{array}$ & $\begin{array}{l}\text { It is not possible to free up } \\
\text { time to apply SE principles: } \\
\text { the project constraints } \\
\text { ("firefighting") prevail over } \\
\text { SE deployment. }\end{array}$ & $\begin{array}{l}\text { Beginning of mind changes: } \\
\text { the short-term constraints of } \\
\text { project management are not } \\
\text { incompatible with SE } \\
\text { deployment. }\end{array}$ & $\begin{array}{l}\text { Projects managers understand } \\
\text { that PM and SE have the same } \\
\text { ultimate project goal and while } \\
\text { being delivery-oriented, the PM } \\
\text { will have to allocate time to the } \\
\text { project members to apply SE } \\
\text { principles. }\end{array}$ & $\begin{array}{l}\text { Projects managers try to find } \\
\text { out how to introduce SE in } \\
\text { their projects in a pragmatic } \\
\text { way. }\end{array}$ \\
\hline $\begin{array}{l}\text { Involvement of } \\
\text { managers in the SE } \\
\text { deployment project }\end{array}$ & Missing. & Low involvement. & $\begin{array}{l}\text { Managers divided on SE: a } \\
\text { substantial part is } \\
\text { nevertheless convinced. }\end{array}$ & $\begin{array}{l}\text { Most of managers are } \\
\text { convinced of the relevancy of } \\
\text { SE but a substantial part is also } \\
\text { involved in actions of } \\
\text { deployment preparation. }\end{array}$ & $\begin{array}{l}\text { Managers are convinced of } \\
\text { the relevancy of SE and are } \\
\text { involved in actions of } \\
\text { deployment preparation. }\end{array}$ \\
\hline \multicolumn{6}{|c|}{ METHODS \& TOOLS } \\
\hline \multicolumn{6}{|c|}{ KNOWLEDGE MANAGEMENT AND SHARING } \\
\hline $\begin{array}{l}\text { Capacity to exchange } \& \\
\text { share information } \\
\text { within the entity }\end{array}$ & $\begin{array}{l}\text { Isolated systems (No } \\
\text { connection). }\end{array}$ & $\begin{array}{l}\text { Connected systems } \\
\text { (Electronic connection) - } \\
\text { Separate data \& } \\
\text { applications. }\end{array}$ & $\begin{array}{l}\text { Basic collaboration - Separate } \\
\text { data and applications. Some } \\
\text { shared data may exist but the } \\
\text { sharing/search is difficult. }\end{array}$ & $\begin{array}{l}\text { Sophisticated collaboration - } \\
\text { Shared data. } \\
\text { "Separate" applications. }\end{array}$ & $\begin{array}{l}\text { Advanced collaboration - } \\
\text { Interactive manipulation - } \\
\text { Shared data and applications. }\end{array}$ \\
\hline $\begin{array}{l}\text { Capitalization, } \\
\text { formalization and } \\
\text { sharing of knowledge } \\
\text { about design } \\
\text { engineering activities }\end{array}$ & $\begin{array}{l}\text { No capitalisation or } \\
\text { formalisation of } \\
\text { knowledge, know-hows, } \\
\text { vocabulary and guidance } \\
\text { within the entity. }\end{array}$ & $\begin{array}{l}\text { Some initiatives to } \\
\text { capitalize on entity's } \\
\text { knowledge, know-hows and } \\
\text { vocabulary about design } \\
\text { engineering activities, but } \\
\text { not disseminated. Guidance } \\
\text { is available. }\end{array}$ & $\begin{array}{l}\text { Some initiatives to capitalize } \\
\text { on entity's knowledge, know- } \\
\text { hows and vocabulary about } \\
\text { design engineering activities } \\
\text { and disseminated within the } \\
\text { entity. However access to } \\
\text { information is not known by } \\
\text { all. }\end{array}$ & $\begin{array}{l}\text { Entity's knowledge, know-hows } \\
\text { and vocabulary about design } \\
\text { engineering activities are } \\
\text { capitalized and disseminated } \\
\text { within the entity. Access to } \\
\text { information is known by all } \\
\text { involved. Help to find } \\
\text { information is also provided. }\end{array}$ & $\begin{array}{l}\text { Technical watch about design } \\
\text { engineering activities and SE } \\
\text { is done and is accessible for } \\
\text { all people involved. It is } \\
\text { analysed and influence the } \\
\text { current way of designing } \\
\text { product if relevant for the } \\
\text { entity. }\end{array}$ \\
\hline $\begin{array}{l}\text { Capitalization, } \\
\text { formalization and } \\
\text { sharing of knowledge } \\
\text { about design technical } \\
\text { management }\end{array}$ & $\begin{array}{l}\text { No capitalisation or } \\
\text { formalisation of } \\
\text { knowledge, know-hows, } \\
\text { vocabulary and guidance } \\
\text { within the entity. }\end{array}$ & $\begin{array}{l}\text { Some initiatives to } \\
\text { capitalize on entity's } \\
\text { knowledge, know-hows and } \\
\text { vocabulary about design } \\
\text { technical management. } \\
\text { However, no dissemination } \\
\text { effort is performed. } \\
\text { Guidance is available. }\end{array}$ & $\begin{array}{l}\text { Some initiatives to capitalize } \\
\text { on entity's knowledge, know- } \\
\text { hows and vocabulary about } \\
\text { design technical management. } \\
\text { Dissemination effort is } \\
\text { performed within the entity, } \\
\text { but access to information is } \\
\text { not known by all. }\end{array}$ & $\begin{array}{l}\text { Entity's knowledge, know-hows } \\
\text { and vocabulary about design } \\
\text { technical management are } \\
\text { capitalized and disseminated } \\
\text { within the entity. Access to } \\
\text { information is known by all. } \\
\text { Help to find information is also } \\
\text { provided. }\end{array}$ & $\begin{array}{l}\text { Technical watch about design } \\
\text { technical management is done } \\
\text { and is accessible by all people } \\
\text { concerned. It is analysed and } \\
\text { influence the current way of } \\
\text { designing product, if relevant } \\
\text { for the entity. }\end{array}$ \\
\hline $\begin{array}{l}\text { Sharing of artefacts } \\
\text { templates }\end{array}$ & No sharing. & $\begin{array}{l}\text { Templates of artefacts used } \\
\text { in some projects are shared } \\
\text { on demand. }\end{array}$ & $\begin{array}{l}\text { Templates of artefacts used in } \\
\text { some projects are available } \\
\text { for all within the entity. } \\
\text { However artefacts to use are } \\
\text { not standardised within the } \\
\text { entity. }\end{array}$ & $\begin{array}{l}\text { High level artefacts are } \\
\text { standardised within the entity } \\
\text { and their templates are shared } \\
\text { within the entity. }\end{array}$ & $\begin{array}{l}\text { Low level artefacts are } \\
\text { standardised within the entity } \\
\text { and their templates are shared } \\
\text { within the entity. }\end{array}$ \\
\hline \multicolumn{6}{|c|}{ TOOLS } \\
\hline $\begin{array}{l}\text { Design tools } \\
\text { standardization }\end{array}$ & $\begin{array}{l}\text { No tool management. } \\
\text { "One tool by person" } \\
\text { possible. }\end{array}$ & $\begin{array}{l}\text { Standardisation of design } \\
\text { tools by team. }\end{array}$ & $\begin{array}{l}\text { Standardisation of design } \\
\text { tools within each project but } \\
\text { not between projects. }\end{array}$ & $\begin{array}{l}\text { Standardisation of design tools } \\
\text { between all projects. }\end{array}$ & $\begin{array}{l}\text { Technical watch about design } \\
\text { tools is done and is accessible } \\
\text { for all people concerned. It is } \\
\text { analysed and influences the } \\
\text { selection of design tools used } \\
\text { within the entity. }\end{array}$ \\
\hline
\end{tabular}

$N B: S E=$ Systems Engineering, $M B S E=$ Model Based Systems Engineering, $R \& R=$ Roles and responsibilities, PM $=$ Project management. 